\title{
HYPOTHETICAL LEARNING TRAJECTORY IN REALISTIC MATHEMATICS EDUCATION TO IMPROVE THE MATHEMATICAL COMMUNICATION OF JUNIOR HIGH SCHOOL STUDENTS
}

\author{
Ida Nuraida ${ }^{1}$, Asep Amam*2
}

${ }^{1,2}$ Universitas Galuh

\section{Article Info}

Article history:

Received Sept 2, 2019

Revised Sept 26, 2019

Accepted Sept 27, 2019

\section{Keywords:}

Design Research,

HLT,

Learning Trajectory,

Mathematical Communication

RME

\begin{abstract}
This research was motivated by the difficulties of junior high school students in linear equation system material. The focus of this research is to produce the Hypothetical Learning Trajectory (HLT) system of linear equations based on the development of Learning Trajectory (LT) with the aim of research to improve students' mathematical communication skills. Research method used design Research with 3 phases: Preliminary design, teaching experiment, and retrospective analysis. The subject of study in SMP grade VII in Tasikmalaya district. This research uses the instrument of communication skills test students. Processing of research data using test-T. Based on the results of the research obtained: (a) HLT results from the development of LT linear alignment system in RME to improve student mathematical communication skills; and (b) students who acquire RME learning have increased mathematical communication skills greater than those who acquire conventional learning.
\end{abstract}

Copyright (C) 2019 IKIP Siliwangi. All rights reserved.

Corresponding Author:

Asep Amam,

Departement of Mathematics Education,

Universitas Galuh,

Jl. R. E. Martadinata No.150, Ciamis, West Java 46274, Indonesia.

Email: asepamam85@Gmail.com

\section{How to Cite:}

Nuraida, I., \& Amam, A. (2019). Hypothetical learning trajectory in realistic mathematics education to improve the mathematical communication of junior high school students. Infinity, 8(2), 247-258.

\section{INTRODUCTION}

The purpose of learning mathematics in Indonesia based on the National Education Standards Agency is that students can develop mathematical abilities. The intended abilities include the ability to understand mathematical concepts, the ability to use reasoning on patterns and traits, the ability to solve problems that include the ability to understand problems, the ability to have an attitude of appreciating the usefulness of mathematics in life, and the ability to communicate ideas with symbols, tables, diagrams, or media another to clarify the situation or problem. This explains that mathematical communication skills are very important possessed by students because by having good mathematical communication skills, students are able to verbally or in writing 
communicate mathematical ideas or ideas with symbols, tables, graphs, diagrams, or other media to clarify the situation or problem.

Difficulties experienced by students are caused by several factors, including: (1) the learning approach factor, the learning approach used in learning lacks building students' thinking abilities and problem-solving abilities according to the opinion of Kansanen (2003). Some things that characterize learning practices in Indonesia are generally teachercentered learning; (2) the factor of study habits, students are only accustomed to learning by memorizing, this method is not so training in thinking skills and problem-solving abilities, this method is the result of learning that teachers normally use is conventional learning, where students are crammed with concepts, examples of questions, then the matter of practice according to Anwar, Budayasa, Amin, \& de Haan (2012). Related to efforts to improve communication skills, teachers are expected to think about the Hypothetical Learning Trajectory (HLT) through realistic mathematics learning (RME) that will occur in mathematics learning, so that communication skills can be improved, Prahmana \& Suwasti (2014) RME learning is learning that has 4 aspects namely using context, using models, interactivity, utilizing construction results, and interrelationships (Nuraida, 2017, 2018).

RME is an approach to learning mathematics. Learning that uses a realistic mathematical approach does not begin with teaching formal mathematics, but rather to appreciate and understand the importance of mathematics as a human activity. The learning process is carried out in stages through the initial knowledge of mathematics that students already have, presenting problems and the results obtained through vertical and horizontal mathematical processes called mathematical progressives. In the principles of realistic mathematics learning, horizontal mathematical consists of three levels, namely: (1) mathematical world orientation; (2) material models; (3) building stone number relation. RME is a teaching approach that starts from 'real' things for students, emphasizes process skills, discusses and collaborates, argues with classmates so they can find their concepts in solving mathematical problems. One of the main principles of the RME is guided reinvention.

According to the principle of reinvention in learning mathematics, it should have endeavored that students have experience in discovering their various concepts, principles, or procedures, with the guidance of the teacher. RME has three main principles formulated by Gravemeijer (2004), namely: (1) Guided reinvention and progressive mathematizing; (2) Didactical phenomenology is a phenomenon; and (3) Self-developed model.

Guided reinvention and progressive mathematizing is rediscovering through progressive mathematization, which states that RME-based learning must provide the broadest opportunity to rediscover concepts or algorithms. Students can think from informal mathematics to move towards formal mathematics with the capital of understanding that has been derived from previous student knowledge. The teacher's task in terms of learning is as a companion and guide to go to a mathematical concept that will be found again.

Didactical phenomenology is a phenomenon that was the character of educating. Expected phenomena that are educational in nature that emphasize the importance of contextual problems delivered to students following the level of knowledge students have when learning occurs. Learning will be meaningful if the contextual issues of education are following the resolution of contextual problems in learning.

Self-developed model are models developed by students must be able to bridge between informal knowledge and formal knowledge. Students independently develop mathematical models in solving contextual problems. Learning RME, which acts as a key or starting point in problem-solving, is contextual. 
Realistic Mathematics (RME) is an approach to learning mathematics, which was initially applied by Freudhental in the Netherlands in 1971. Furthermore, Treffers (Zulkardi \& Putri, 2010) defines it as follows: 1) Mechanistic, this approach is often referred to as the traditional approach based on drill and practice and patterns. This approach regards students as a machine (mechanic), 2) Empirically, this approach assumes that the world is realistic, which makes students faced with a situation that requires them to use horizontal mathematical activities, 3) Structuristic, this approach is based on set theory and games that can be categorized into horizontal mathematical. But it is determined from the world created according to needs, which have nothing in common with the world of students, 4) Realistic, which is an approach that uses real-world situations or a context as a starting point in learning mathematics.

At this stage, students do horizontal mathematical activities, which is when students organize a problem and try to identify the mathematical aspects that exist in the issue. Then, using vertical mathematical students arrive at the concept formation stage. Realistic mathematics combines what mathematics views are, how students learn mathematics, and how mathematics should be taught. To design a learning model based on PMRI theory, the model must present PMRI characteristics both on objectives, material, methods, and evaluation (Armanto, 2002).

RME has five characteristics, namely: 1) Using context, context is the environment experienced by students in daily life; 2) Using a model, the model is taken from everyday life both real and that students can imagine, then directs the model to a more abstract symbol; 3) Using student contributions, in principle the constructing material is students themselves, in this case, student contributions are needed, so students are encouraged to be active in learning; 4) Interactivity, in this learning cooperation is needed, both between students and students and between students and teachers, so that communication occurs in learning; 5) Integrated with other learning topics, discussion of certain material is related to other knowledge, so that learning will be effective and efficient (Armanto, 2002).

The ability of mathematical communication is the ability to convey mathematical ideas/ideas, both orally and in writing as well as the ability to understand and accept mathematical ideas/ideas of others carefully, analytically, critically, and evaluatively, to sharpen the understanding. Indicators of mathematical communication skills include: Connecting real objects, pictures, and diagrams into mathematical ideas; Explain numerical or verbal concepts, situations, and relationships with real objects, images, graphics, and algebraStates everyday events in mathematical language; Listening, discussing, and writing about mathematics; Read with an understanding of a written mathematics presentation; Compile accurate questions that are relevant to the problem situation; Make conjectures, arrange arguments, formulate definitions, and generalizations.

Also, it also states that mathematical communication skills are abilities that can include and contain various opportunities to communicate in the form of: Reflect real objects, pictures, and diagrams into mathematical ideas; Model the situation or problem using oral, written, concrete, graphical, and algebraic methods; State everyday events in precise language or symbols; Listen, discuss, and write about mathematics; Read with an understanding of a written mathematical presentation; Make connectors, arrange arguments, formulate definitions, and generalizations; Explain and make questions about mathematics that have been learned.

The indicators of mathematical communication in this study are (1) stating a situation into a mathematical model, (2) creating a problem situation in its own language, and (3) stating a mathematical idea in writing. Nurdin (2011) states that mathematical communication skills are the ability to organize mathematical thoughts, communicate mathematical ideas logically and clearly to others, analyze and evaluate mathematical 
thoughts and strategies used by others, and use mathematical language to express ideas appropriately.

Indicators of mathematical communication skills are as follows: Arrange and consolidate their mathematical thinking through communication; Communicate their mathematical thinking logically and clearly with other students or with the teacher; Analyze and evaluate the mathematical thinking and strategies of others; Use precise language to express mathematical ideas appropriately.

The indicators of communication skills to be achieved in this study: States the system statement of linear equations (drawing aspects); Explain the strategy for solving a problem of systems of linear equations (writing elements); Presenting the solution of problems of linear equation systems in detail and correctly (aspects of mathematical expression).

Student activities are organized so that they can interact with each other for discussion, negotiation, and collaboration. In this situation, they have the opportunity to work, think, and communicate about mathematics. The role of the teacher is limited to the facilitator or supervisor, moderator, and evaluator. In the evaluation material, it is usually made in the form of open-ended questions that lure students to answer freely and use a variety of strategies or a range of answers or free productions. The evaluation must include formative or summative learning, final unit, or topic.

In learning mathematics, by using realistic mathematics, students are expected to be able to come up with models and develop them independently. Model development can be developed using informal models and formal models that are known to them. Beginning with solving contextual problems from real situations that are known and then found 'models of' (models of) these situations (informal forms), and then followed by the discovery of 'models for' (models for) these forms (formal forms), so found the solution to the problem sought in the way of mathematical knowledge standards. Students learn from the real situation stage, the modeling stage (reference), generalization, and end the formal stage (Gravemeijer, 2004).

The use of a model of and model for explained through the theory put forward by Bruner (Yağc1, 2010) that children obtain information through three stages, namely: Enactive stage, namely the stage of learning a knowledge that is learned effectively by using concrete objects or real situations; The iconic stage, namely the stage of learning a knowledge by presenting it in the form of visual imagery, images, or diagrams which are representations of concrete objects at the enactive stage; Symbolic stage, namely the learning stage of a knowledge that is presented in the form of abstract symbols, namely the arbiter symbols used based on the commitment of experts in the field concerned.

According to Prahmana \& Suwasti (2014), the development of HLT is formulated in three components, namely: 1) learning objectives; 2) learning instruments to be used; 3 ) hypothetical learning process that anticipates how students' mathematical thinking processes are developed. Based on this, in developing a learning design it is necessary to formulate a HLT (Gravemeijer, 2004). The term Learning Trajectory (LT) is called HLT because the design is still in the form of guesses or hypotheses. LT is used to describe the transformation that results from participating activities in learning mathematics, also used for a series of learning or learning trajectories. HLT is used as part of what is called the mathematics teaching cycle (mathematical learning cycle) for one or two, even more, learning. HLT consists of three components: learning objectives, which define the direction (learning objectives), learning activities, and hypotheses of the learning process to predict how students' minds and understanding will develop in the context of learning activities (Bakker \& Van Eerde, 2012, 2015). 
There is another term for LT, which is Mathematical Learning Trajectory (MLT), because LT has been pursed in learning mathematics so that the name from LT becomes MLT. Clements \& Sarama (2009) said that Mathematical Learning Trajectory has three important parts, namely: (1) mathematics learning goals to be achieved, (2) developmental trajectories that will be developed by students in achieving learning objectives, and (3) a set of learning activities or assignments that are appropriate to the stages of thinking on the developmental path that will assist students in developing their thought processes even to higher-order thinking processes.

HLT plays a role in each learning phase, the role and position of the HLT in each stage: (1) preparation and design stage: at this stage, HLT is designed to guide the design process of learning materials to be developed and adapted. The confrontation between general thinking and concrete activities often leads to more specific HLT, (2) Experimental design stage: during the learning experiment, HLT serves as a guideline for what teachers will focus on in the learning process, interviews, and observations. The teacher needs to adjust the HLT with learning activities for learning meetings. HLT can change during the teaching experiment phase, (3) Restrospective analysis stage: At this stage HLT acts as a clue in determining the focus of the analysis, because predictions are made related to student learning processes, it can be compared between the anticipation of predictions through observation during learning experiments (teaching experiment). This analysis concerning the interplay between HLT and empirical observations can be the basis for forming the theory. HLT was reformulated based on the findings of views and analyses conducted. The new HLT will be a clue to the next design phase (Bakker \& Van Eerde, 2015)

Based on this, HLT or LT is a learning trajectory that must be passed by students to achieve the desired learning goals, conduct learning activities according to the stages of thinking and development of the learning trajectory, obtain learning hypotheses to be made the didactic design in anticipating didactic situations especially Learning obstacle. It can be concluded that HLT or LT or MLT is a learning trajectory whose contents are similar to those contained in the Learning Implementation Plan (LIP), because in LT or HLT or MLT it contains things that are in the LIP, such as learning objectives to be achieved, learning activities or tasks that fit the stage of thinking. The difference is that the lesson plan does not contain hypotheses or alleged students' understanding.

In the design of learning activities, the learning trajectory plan contains the allegations made by the teacher and is expected to get a response from students for each stage in the learning trajectory. These assumptions are described based on each meeting of an instructional activity plan called the learning trajectory plan (Gravemeijer, 2004). A learning trajectory plan includes 1) learning objectives for students, 2) planned learning activities, and 3) an alleged learning process, where the teacher anticipates the development of their mathematical knowledge in class and how students' understanding develops as they engage in learning activities in their groups (Cobb, Confrey, DiSessa, Lehrer, \& Schauble, 2003).

\section{METHOD}

This research uses a design research method, a technique that aims to design hypothetical learning trajectory (HLT) Cobb et al. (2003). And assessing the improvement of students' communication skills. Gravemeijer \& Cobb (2006) state that there are 3 phases in the implementation of design research, namely: (1) Initial Design; (2) Design of the experiment; and (3) Retrospective analysis. 


\subsection{Phase 1 - Initial Design (preparing for the experiment/preliminary)}

The preliminary design functions to implement the initial ideas obtained from the literature review on the subject matter, namely curvature space building, RME approach, curriculum, and design research as the basis for formulating hypotheses of students' initial strategy in learning curvaceous material. Next is the Hypothetical Learning Trajectory (HLT) designation, which is a series of learning activities to construct curved side spaces using the RME approach in which the HLT contains three aspects. Simon (Bakker \& Van Eerde, 2015) mentions elements contained in HLT, namely: 1) learning objectives; 2) learning activities; and 3) prediction of student thinking. This prediction is dynamic so that it can be adjusted to students' reactions during learning and revised in the teaching experiment process. The forecast is used as a guide to anticipate students' thoughts and strategies that emerge and can develop in learning activities. The results of the study from phase 2 are in the form of design of learning activities to achieve learning objectives that have been made at each stage of learning and prediction of the trajectories of student activities in achieving learning objectives.

The prototype test was held at the Tasikmalaya Regency Middle School with a total of 12 students ( 2 low ability students, seven medium ability students, and three high ability students) from November 2018 to January 2019. The material under study was the Linear Equation System. The first cycle is to test the HLT on the Linear Equation System material contained in the 2013 curriculum. This stage is a design trial.

\subsection{Phase 2 - Design of the experiment (Teaching experiment)}

Simon's (Bakker \& Van Eerde, 2015) state that "mathematical teaching cycle," suggests that teachers should try to guess before the occurrence of students 'mental activities (thought experiment), then try to find the students' thought processes that are actually related to those suspected in the teaching process (teaching experiment). Therefore, the design of this experiment is divided into two experiments: (1) A pilot experiment, which is a bridge between the initial design phase and the teaching experiment. The objectives of the pilot activity are: (a) Tracing the student's fundamental knowledge, (b) collecting data to support the adjustment of the previous learning trajectory plan. (2) The teaching experiment aims as data collection to answer research questions. In the teaching experiment phase, researchers conducted learning in the experimental class with RME learning, while the control class with conventional learning.

In contrast to stage 1, in step 2 the researchers took one school to be a place of research. The second cycle is carried out from January to March 2019. Based on the findings of a retrospective analysis in the second stage, researchers obtain the final recommendations that produce a prototype.

\subsection{Phase 3 - Retrospective Analysis}

In this phase, the data obtained from the teaching experiment phase are analyzed, and the results of the study are used to plan activities and develop activity plans for further learning. In general, the purpose of retrospective analysis is to build LIT. This phase may or may not use the grounded theory method. Grounded theory, namely the development of arguments based on data obtained systematically and analyzed in a social framework (Mills, Bonner, \& Francis, 2006). Grounded theory research there are three sequential stages, namely: 1) open coding; 2) selective coding, and 3) theoretical coding (Jones \& Alony, 2011). Researchers at this phase do not use grounded theory because of limited 
time, funds, and facilities. The phases in this design research are summarized as follows in Figure 1.

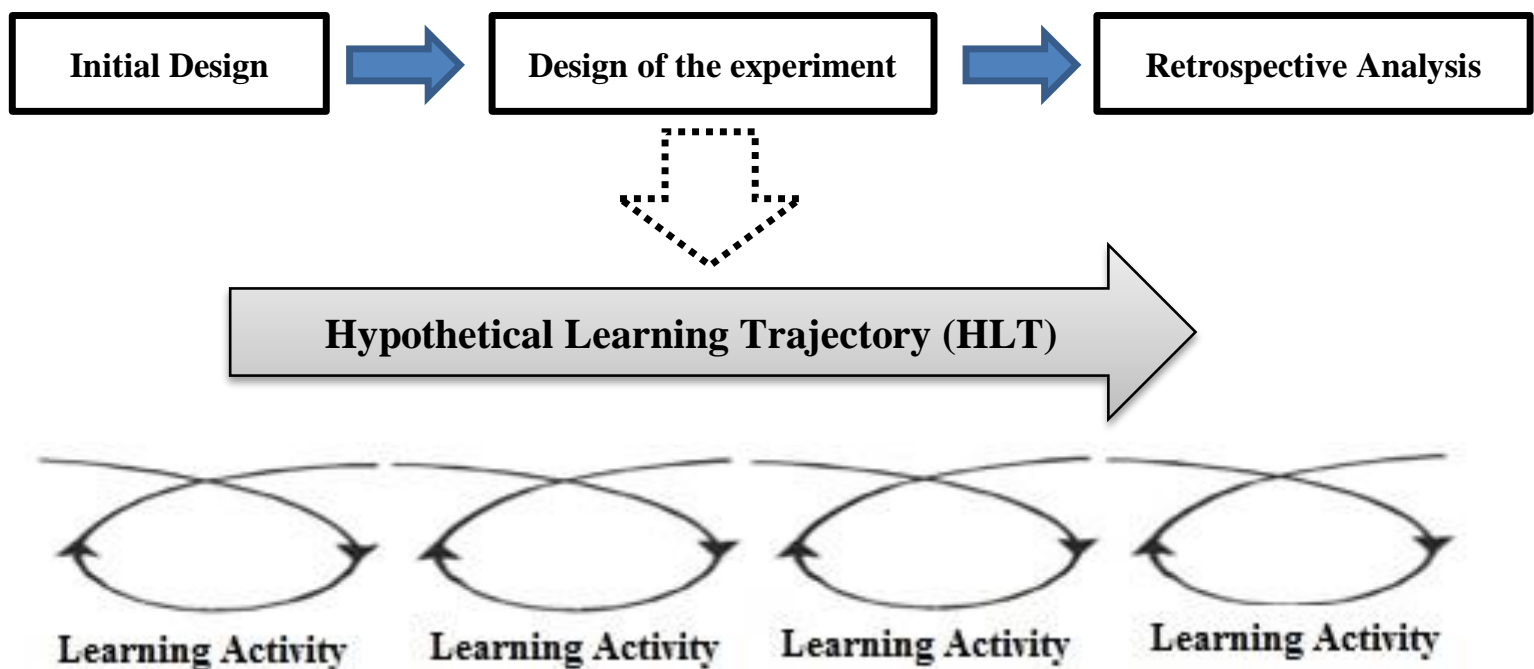

Figure 1. Stages of research design

There are two stages in the study that have been carried out, namely step 1 includes prototype design, HLT trials, and retrospective analysis. Phase 2 consists of the provision of realistic mathematics learning to see an increase in students' mathematical communication skills. The following is a chart of research methods (Figure 2).

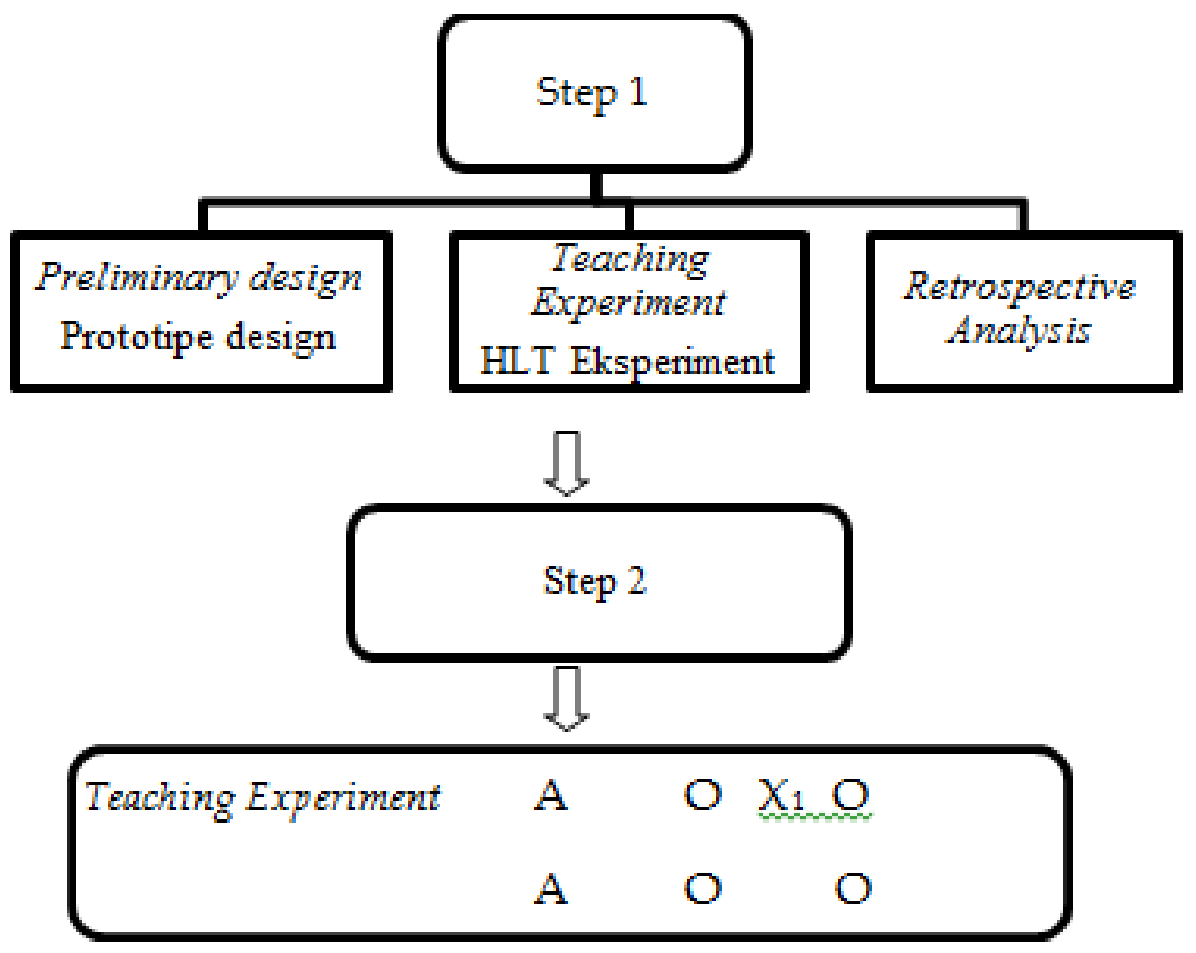

Figure 2. Research Chart 
In stage 1, there are three main steps that must be carried out, namely the preliminary design stage, the second step is the teaching experiment, and the third step is the retrospective analysis. In Phase 2, learning is done in the classroom to see the communication skills of the students obtained.

\section{RESULTS AND DISCUSSION}

\subsection{Results}

In this study the research findings are described which are generally divided into two stages in accordance with the design research stages, namely the first stage begins with the preliminary design, teaching experiment, and ends with a retrospective analysis that has been validated and tested in a limited way (Cobb et al., 2003). This research was conducted by researchers to determine the alleged learning trajectory and see differences in the improvement of students' communication skills between RME learning and conventional learning. The study was conducted at Rajapolah State Junior High School 2 in class VIII, namely class VIII B as an experimental class and class VIII C as a control class using purposive sampling techniques, this aims to determine the presence or absence of differences in the improvement of students' mathematical communication skills after the learning process is carried out.

Based on observations during the study, it was seen that RME learning is learning that can improve student communication skills. In direct learning, the teacher dominates the class more during the learning process, and students look less active, and learning takes place that is less interesting and boring. Some students seem to lack enthusiasm in learning mathematics, it is seen when students are given practice questions, some students are reasonable in order to get out of class to avoid the training given.

After the preliminary stage is carried out, subsequent stages of a teaching experiment, thus experiencing some test results. To see the improvement of mathematical communication skills of students obtained as in the following Table 1.

Table 1. Test-T improved mathematical communication

\begin{tabular}{|c|c|c|c|c|}
\hline \multicolumn{2}{|c|}{ Mean } & \multirow{2}{*}{$\mathbf{T}$} & \multirow{2}{*}{ Sig. } & \multirow{2}{*}{$\mathbf{H}_{\mathbf{0}}$} \\
\hline RME & Konv & & & \\
\hline 0.52 & 0.31 & 4.99 & 0.000 & rejected \\
\hline 0.66 & 0.37 & 3.59 & 0.002 & rejected \\
\hline 0.34 & 0.26 & 2.31 & 0.031 & rejected \\
\hline
\end{tabular}

The T-test result in Table 1 shows the significant value of all less than 0.05 , then the zero hypothesis rejects. It is concluded that increased communication skills using RME learning is better than the student's using conventional learning.

Based on the test results of the average difference and the magnitude of the average value of achieving communication skills between the two learning groups (RME and conventional), it can be concluded: (1) Achievement of communication skills of students who get RME learning better than students who get Conventional learning; (2) Improved communication skills are obtained from the N-Gain calculation between pretest and posttest scores. The calculation results of the improvement of communication skills of the two learning groups are then searched for the mean and the standard deviation; (3) A 
comparison of increased communication skills between the RME and Conventional Groups were analyzed using the Mann-Whitney $U$ test. The reason for using the Mann-Whitney $U$ test was because after the data were tested for normality, it was found that the data were not normally distributed.

\subsection{Discussion}

The preliminary design that has been done is the study of literature, which is at the same time a process of discussion with experienced mathematics subjects in mathematics learning the system of linear equations. The learning design study used in the next stage is the teaching experiment stage. HLT has three components, namely: learning objectives, activities, and learning hypotheses (Cobb et al., 2003). The following are presented alleged learning trajectories in Table 2.

Table 2. HLT Examples in Learning Linear Equation Systems

\begin{tabular}{|c|c|c|}
\hline Learning objectives & Learning activities & Learning hypothesis \\
\hline $\begin{array}{l}\text { HLT Examples in } \\
\text { Learning Linear } \\
\text { Equation Systems } \\
\text { Learning Objectives } \\
\text { Learning activities } \\
\text { Learning hypothesis } \\
\text { Students can find the } \\
\text { concept of one variable } \\
\text { linear equation system } \\
\text { in daily life. }\end{array}$ & $\begin{array}{l}\text { Find the concept of one variable linear } \\
\text { equation. Rahma was told by her } \\
\text { mother to buy a hairpin with Rp. } \\
10,000 \text { and get a change of Rp. } 4,000 \\
\text { Possible questions asked to students. } \\
\text { Teacher: How many hairpins can } \\
\text { Rahma buy? } \\
\text { Student } 1: \text { One-piece } \\
\text { Teacher: how are the similarities? } \\
\text { Student } 1: \text { a }+4,000=10,000 . \\
\text { Teacher: Are there other answers? } \\
\text { Student } 2: 2 \text { pieces } \\
\text { Teacher: write down the equation } \\
\text { Students } 2: 2 \mathrm{a}+4,000=10,000 . \\
\text { Furthermore student } 3 \text { answers } 3 \\
\text { pieces, student } 4 \text { answers } 4 \text { pieces, } \\
\text { student } 5 \text { answers } 5 \text { pieces and so on. } \\
\text { The equation in a row: } \\
3 \mathrm{a}+4,000=10,000 \\
4 \mathrm{a}+4,000=10,000 \\
5 \mathrm{a}+4,000=10,000 \\
6 \mathrm{a}+4,000=10,000 \text { Students are able } \\
\text { to recognize the form of the system of } \\
\text { equations and are able to improve } \\
\text { communication skills. }\end{array}$ & $\begin{array}{l}\text { Students can recognize } \\
\text { the form of a system of } \\
\text { equations and can } \\
\text { improve their } \\
\text { communication skills. }\end{array}$ \\
\hline
\end{tabular}

Based on students' activities in discovering the concept of a single variable linear equation system in daily life can vary in the answer Nuraida, Kusumah, \& Kartasasmita (2018), because it is an open matter. Teachers should have many allegations that happened 
to the student's activities (Wilson, Sztajn, Edgington, \& Confrey, 2014). The expected objective of the matter is that students discover the concept of equations so that students can use the "=" sign.

\section{CONCLUSION}

The results of this study can be concluded that the alleged study trajectory that will occur in students' activities is very much so that the teacher, in this case, should prepare a more mature trial. This research is certainly not separated from the constraints experienced by students from the preliminary stage to the retrospective stage. These constraints exist at the preliminary stage because of not ready teachers in designing learning paths. The communication skills of students using RME learning are better than students using conventional learning.

\section{ACKNOWLEDGEMENTS}

We thank to DRPM Kemenristek Dikti that has given funding for research; Head of LLDikti Region IV that has give fascilitation; Rector of Universitas Galuh Ciamis; Head of LPPM Universitas Galuh Ciamis.

\section{REFERENCES}

Anwar, L., Budayasa, I. K., Amin, S. M., \& de Haan, D. (2012). Eliciting Mathematical Thinking of Students through Realistic Mathematics Education. Indonesian Mathematical Society Journal on Mathematics Education, 3(1), 55-70.

Armanto, D. (2002). Teaching Multiplication and Division Realistically in Indonesian Primary Schools: A Prototype of Local Instruction Theory. Thesis. The University of Twente.

Bakker, A., \& Van Eerde, D. (2012). An introduction to design-based research for Master and PhD students. Doing (qualitative) Research: Methodology and methods in Mathematics Education. Concept submitted for publication March, 15, 2012.

Bakker, A., \& Van Eerde, D. (2015). An introduction to design-based research with an example from statistics education. In Approaches to qualitative research in mathematics education (pp. 429-466). Springer, Dordrecht.

Clements, D. H., \& Sarama, J. (2009). Learning trajectories in early mathematicssequences of acquisition and teaching. Encyclopedia of language and literacy development, 1-7.

Cobb, P., Confrey, J., DiSessa, A., Lehrer, R., \& Schauble, L. (2003). Design experiments in educational research. Educational researcher, 32(1), 9-13.

Gravemeijer, K. (2004). Local instruction theories as means of support for teachers in reform mathematics education. Mathematical thinking and learning, 6(2), 105-128.

Gravemeijer, K., \& Cobb, P. (2006). Design research from a learning design perspective. In Educational design research (pp. 29-63). Routledge.

Jones, M., \& Alony, I. (2011). Guiding the use of grounded theory in doctoral studies-An example from the Australian film industry. 
Kansanen, P. (2003). Studying--the realistic bridge between instruction and learning. an attempt to a conceptual whole of the teaching-studying-learning process. Educational Studies, 29(2-3), 221-232.

Mills, J., Bonner, A., \& Francis, K. (2006). The development of constructivist grounded theory. International journal of qualitative methods, 5(1), 25-35.

Nuraida, I. (2017). Merancang Uji Coba Realistic Mathematics Education (RME). SJME (Supremum Journal of Mathematics Education), 1(2), 68-78.

Nuraida, I. (2018). Penerapan Pembelajaran Matematika Realistik untuk Meningkatkan Kemampuan Adaptive Reasoning Siswa. Mosharafa: Jurnal Pendidikan Matematika, 7(1), 25-32.

Nuraida, I., Kusumah, Y. S., \& Kartasasmita, B. G. (2018). Local Instruction Theory (LIT) on spherical geometry for enhancement students' strategic competence. In Journal of Physics: Conference Series, 983(1), 012105.

Nurdin, N. (2011). Trajektori dalam Pembelajaran Matematika. Edumatica, 1(1), 1-7.

Prahmana, R. C. I., \& Suwasti, P. (2014). Local instruction theory on division in mathematics GASING. Journal on Mathematics Education, 5(1), 17-26.

Wilson, P. H., Sztajn, P., Edgington, C., \& Confrey, J. (2014). Teachers' use of their mathematical knowledge for teaching in learning a mathematics learning trajectory. Journal of Mathematics Teacher Education, 17(2), 149-175.

Yağc1, F. (2010). The effect of instruction with concrete models on eighth grade students' probability achievement and attitudes toward probability. M. Ed. Unpublished master's thesis). Middle East Technical University, Ankara.

Zulkardi, Z., \& Putri, R. I. I. (2010). Pengembangan blog support untuk membantu siswa dan guru matematika Indonesia belajar pendidikan matematika realistic Indonesia (PMRI). Jurnal inovasi perekayasa pendidikan (JIPP), 2(1), 1-24. 
